\title{
Nem-Alıcı ve Buharlaşma-Soğutmalı Hava Şartlandırma Sistemlerinin Çay Fabrikalarında Kullanılabilirliğinin Termodinamik Analizi
}

\author{
Betül SARAÇ*1 \\ ${ }^{1}$ Karadeniz Teknik Üniversitesi, Sürmene Deniz Bilimleri Fakültesi, Gemi İnşaatı ve Gemi \\ Makineleri MühendisliğiBölümü, 61530, Trabzon
}

(Alınıș / Received: 13.03.2017, Kabul / Accepted: 31.05.2017 Online Yayınlanma/ Published Online: 20.09.2017)

Anahtar Kelimeler Nem alma, Buharlaşma soğutma,

Hava

İklimlendirme, Atık 1Sl,

Özet: Nem-alıcılı ve buharlaşma-soğutmalı (NABS) hava şartlandırma sistemleri ülkelerin coğrafik ve iklim şartlarına bağlı olarak değișik șekillerde yaygınca kullanıldığı görülmektedir. Bu sistemlerde nem alma ișlemleri katı veya sıvı higroskopik malzemelerin üzerine ișlem havasının üflenmesiyle gerçekleştirilmektedir. Soğutma işlemi ise işletme havasının doğrudan ve dolaylı buharlaşma soğutulmasıyla sağlanmaktadır. $\mathrm{Bu}$ çalıșmada Doğu Karadeniz'de (Rize) mevcut çay endüstrilerindeki atık ısıların veya değişik şekillerdeki enerjinin bu tip soğutma sistemlerinde kullanılmasıyla yaz aylarında ortam ve yaşam mahallerinin iklimlendirmesinde kullanılmasının, termodinamik kullanılabilirliliğinin alt ve üst limitleri belirlenmiștir. Cay fabrikalarından atılan atık havanın doğrudan rejenerasyon havası olarak kullanılması dış havanın neminin konfor şartlarına getirilmesinde büyük katkı sağladığı görülmüştür.

\section{Thermodynamic Analysis the Usage of Air Conditioning Systems with Dehumidifier and Evaporative-Cooling Capabilities in Tea Plants}

\section{Keywords}

Dehumidification, Evaporative

Cooling,

Air conditioning,

Waste heat,

\begin{abstract}
Dehumidifier-Evaporative-Cooling systems (DEAS) are widely used in different engineering solutions depending on the geographical and climatic conditions of the regions. In these systems, dehumidification is achieved by blowing system air onto solid or liquid hygroscopic materials. Cooling is achieved by direct or indirect evaporative process of the running system. In this study, lower and upper limits of the thermodynamic usage of waste heat energy of the existing tea industries are investigated in terms of usability in inner spaces climatology of the tea producing factories in the Eastern Black Sea region (Rize). The use of waste air from tea factories as directly regeneration air, major contribution is seen when the outside air moisture is brought to the comfort conditions.
\end{abstract}


B. SARAÇ. / Nem-alıcılı ve Buharlaşma-Soğutmalı Hava Şartlandırma Sistemlerinin Çay Fabrikalarında Kullanılabilirliğinin Termodinamik Analizi

\section{Giriş}

Suyun doğrudan ortam havasında buharlaşmasıyla, ortam havasının soğutulması eskiden beri kullanılan bir iklimlendirme yöntemidir. Bu yöntemin teknolojik uygulamalarında insan sağlığına zarar veren Lejyoner hastalığı ortaya çıkmaktadır. Buna engel olmak için dolaylı buharlaştırıcılar geliştirilmiştir. Böylece basit görülen doğrudan buharlaşmalı soğutma uygulanmasının maliyetlerinde göreceli artışlar olmaktadır. Dolaylı buharlaşmalı soğutucuların performansı, doğrudan buharlaşmalı soğutuculara göre düșük olmasına rağmen sağlık açısından uygulamada tercih edilmektedir [2].

$\mathrm{Bu}$ yöntemle elde edilebilecek ortam havası konfor şartları, ortama gönderilen havanın yaş termometre sıcaklığı ile sınırlı kalmaktadır. Doğal olarak dış hava bağıl neminin düşük olduğu iklim koşullarında bu yöntemin uygulanması çok etkilidir [1]. Dış hava bağıl neminin yüksek olduğu coğrafik bölgelerde dolaylı buharlaşmalı soğutma sistemleri bir ön nem alıcl ünite ile birlikte kullanılmaktadır. Bir nem alıcıda bağıl nemi azaltılan dıș hava, dolaylı yollu buharlaştırıcıdan geçirilerek hem bağll nemi hem de sıcaklığı istenen konfor şartlarına getirilir. Görüldüğü üzere bu süreçlerde nem ve sıcaklık kontrolleri ayrı ayrı yapılabilmektedir. Nem-alıcil-buharlaşma-soğutmalı (NABS) iklimlendirme işlemi, yaşam mahaline gelen dıș havanın bağıl neminin nem alıcılarla düșürülmesinin ardından havaya püskürtülen suyun buharlaşmasıyla soğutulması ișlemidir. Nem alıcılı-buharlaştırmalı soğutma literatürde Desesif-Evaporatif-Cooling veya Desiccant Based Evaporative Cooling olarak adlandırılmaktadır $[2,3,4,5,6]$.

Türkiye'nin ılıman ve en nemli bölgesi olan Doğu Karadeniz bölgesinin sahil șeridindeki çay üretim endüstrisinde olușan atık enerjinin, bina yaz iklimlendirmesinde kullanılabilirliğinin Termodinamik açıdan değerlendirilmesi bu çalışmanın amacını teşkil etmektedir. $\mathrm{Bu}$ çalışmada atmosferik hava şartları için Rize'nin iklim şartları ve coğrafi konumu göz önüne alınmıștır.

\subsection{Kimyasal maddeler kullanarak nemli havanın neminin azaltılması}

Havadan kimyasal yöntemle nem alma işleminde higroskopik maddeler kullanılır. $\mathrm{Bu}$ maddeler fiziksel yapı bakımından katı veya sıvı fazda bulunurlar. Kimyasal yolla havadan nem alma ișlemi katı malzemelerle yapılırsa bu işlem adsorpsiyon, sıvı maddelerle yapilırsa bu işlem absorbsiyon olarak adlandirılır [2]. Her iki metot da su buharının maddeye geçişi, su buharının kısmi basıncı ile kimyasal maddenin kısmi basıncı arasındaki farka bağlıdır. Nem alma ișleminde havadaki su buharının kısmi basıncl kimyasal maddenin kısmi basıncından büyük olursa havadaki nem kimyasal madde tarafindan yutulur. Bu nedenle havadan nem almada kullanılan kimyasal maddelere yutucu denmektedir. Böylelikle havanın nemi azalır ve kimyasal madde doyma noktasına erişince nem alma işlemi sona erer. Doyma noktasına erişen kimyasal madde ısıtılıp tekrar eski şartlarına getirilerek, gelecek çevrim için kullanıma hazır hale getirilir. Bu işlem rejenerasyon olarak adlandirılır. Isıtma ișlemi için gerekli olan 1Sı, endüstriyel işlemlerdeki atık ısının geri kullanımı veya yenilenebilir enerji kaynaklarının kullanılmasıyla elde edilebilir. Enerji verimliliği göz önüne alındığında, ișlemin atık ısı veya yenilenebilir enerji kaynaklarına dayalı kullanılabilmesi nem-alıcılı-buharlaşmalı sistemin tercih edilme nedeni olarak görülmektedir.

Silika-jel, aktifleștirilmiș alüminyum ve aktifleştirilmiş boksit gibi maddeler, 
B. SARAÇ. / Nem-alıcılı ve Buharlaşma-Soğutmalı Hava Şartlandırma Sistemlerinin Çay Fabrikalarında Kullanılabilirliğinin Termodinamik Analiz

katı nem alıcı maddeler olarak bilinirler. Bunların su buharına karşı afinitleri çok yüksektir. Bunlar sıvı nem alıcılara göre daha düşük rejenerasyon sıcaklıklarında kullanılırlar. Bunun yanında kullanım hacmi açısından büyük hacim işgal etmeleri ve gözenekli yapılarının zaman zaman tıkanması kullanım zorluğu olarak ortaya çıkmaktadır. Son zamanlarda sıvı nem alıclarının kullanılması yaygınlaşmıştır. Sıvı nem alıclarının zehir etkilerinin olmaması ve çevreye uyumlu özelliklere sahip olması gerekliliği öne çıkmaktadır. Tarihsel kullanım açısından sıvı nem tutucuları incelendiğinde bilinen nem alıclarının suda çözünen tuzlar olduğu görülmektedir. $\mathrm{CaCl}_{2}$ ve $\mathrm{LiCl}$ bilinen bu tuzlardan başlıca iki tanesidir. İki tuz ekonomik olarak karşılaştırıldığında $\mathrm{CaCl}_{2}$ daha ucuzdur. Bunun yanında $\mathrm{LiCl}$ nem alma işleminde daha etkin olduğundan, iki tuzun karıştırılmasından elde edilen karışımlar tercih edilmektedir [1,2]. Nem-alıcılı-buharlaştırmalı soğutma sistemlerinin genel çalışma prensibi Şekil 1' de verilmiştir. Şartlandırılacak hava (genellikle atmosfer havası) nem alma ünitesinden geçirildikten sonra bir soğutucudan geçirilerek, havanın istenen bağll nem seviyesine ve kuru termometre sıcaklığına düşürülmesi sağlanır. Bu işlemde önemli olan nem alıcıdaki higroskopik maddenin nem konsantrasyonunu düșürmektir. Bu işlem için (Rejenerasyon) bir isıtma işlemi gerekmektedir. Bunun için IS1 kaynağı olarak genellikle güneş enerjisi veya yüksek sıcaklıktaki atık ısı enerjisi kullanılmaktadır. Rejenerasyonda üretilen nem tekrar atmosfere gönderilmektedir [1,2].

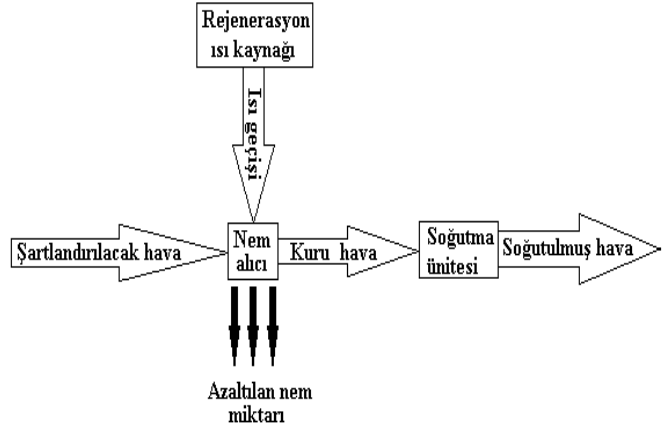

Şekil 1. Nem-alıcılı ve buharlaștırmalı soğutma sisteminin genel çalışma prensibi.

\section{Materyal ve Metot}

Çay fabrikasına, geleneksel NABS hava şartlandırma sisteminin uygulanmasının Termodinamik modellenmesi için fabrikanın baca gazı emisyon ölçüm sonuçları alınmıştır. Çay fabrikasında kayıp ısıların büyük bir kısmı baca gazlarından ve çay kurutma firınlarından atmosfere atılan egzoz havasında görülmektedir. Özellikle $\% 11$ bağll nemde ve $70^{\circ} \mathrm{C}$ kuru termometre sıcaklığında atmosfere doğrudan atılan egzoz hava miktarı ve enerji miktarı çok büyük olup, yaklaşık $10.58 \mathrm{~kg} / \mathrm{s}$ debide $425 \mathrm{~kW}$ olarak hesaplanmıştır. Bu atık ısının, fabrika, çay depolama mekanları ve ofis binalarının havasının soğutulmasında kullanılması amacıyla bir geleneksel NABS hava şartlandırıcısı tasarlanmıștır. Tasarlanan bu NABS hava şartlandırıcısının, çay kurutma firınlarından atılan sıcak ve nemli havayla kullanılmasının termodinamik potansiyelinin araştırılması amacıyla ele alınan termodinamik modeli, üç ayrı ișletim durumuna göre ayrı ayrı Sekil. 2 de gösterilmiştir. Termodinamik modelin üç ayrı çevrimi, Pennington çevriminin değiştirilmiş şeklidir [4]. Tasarlanan NABS hava şartlandırıcısı sisteminde bir döner nem alıcılı (döner rejeneratör) ve dolaylı buharlaștırmalı soğutma sistemi seçilmiş, çay kurutma firınlarındaki sıcak atık enerjisi rejenerasyon için kullanılmıştır. Çevrimde kullanılan atık ısının enerji geri kazanım değeri Pennigton 
B. SARAÇ. / Nem-alıcılı ve Buharlaşma-Soğutmalı Hava Şartlandırma Sistemlerinin Çay Fabrikalarında Kullanılabilirliğinin Termodinamik Analizi

çevriminde kullanılan elektrik enerjisiyle karşılaştırılmıştır.

Termodinamik model ve uygulanan üç ayrı işletim durumunun parametreleri için, çevrimleri ve sistemin değiştirilmiş halleri Şekil 2., Şekil 3. Ve Şekil 4. de şematik olarak çizilmiştir. Şekil 5., Şekil
6. ve Şekil 7. de bu işlemlere ait Termodinamik süreçler psikometrik diyagram üzerinde gösterilmiştir. Sistemde kullanılan doğrudan ve dolaylı buharlaşmalı soğutucuların şematik gösterimleri Şekil 8. de verilmektedir.

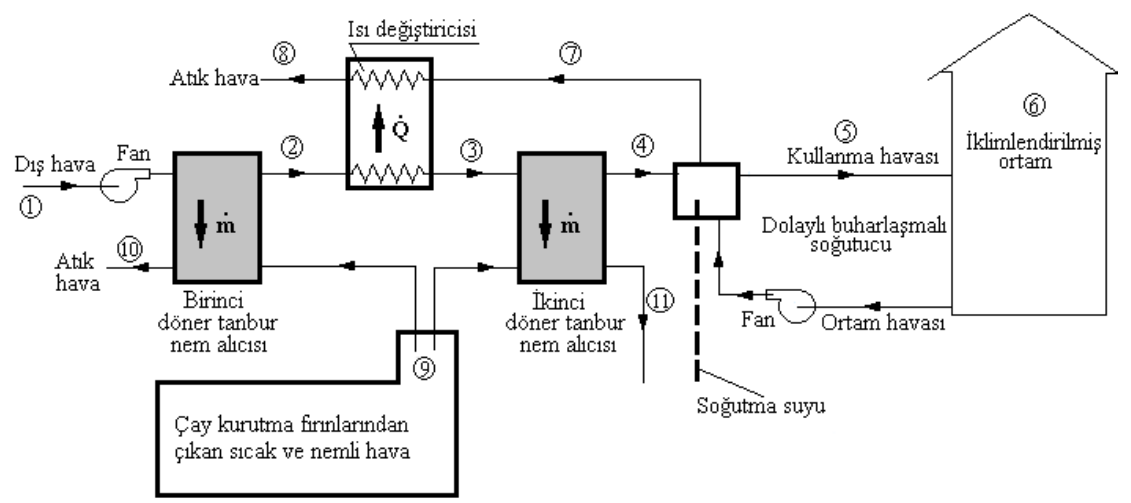

Şekil 2.Birinci işletim parametrelerine dayalı sistemin şematik resmi.

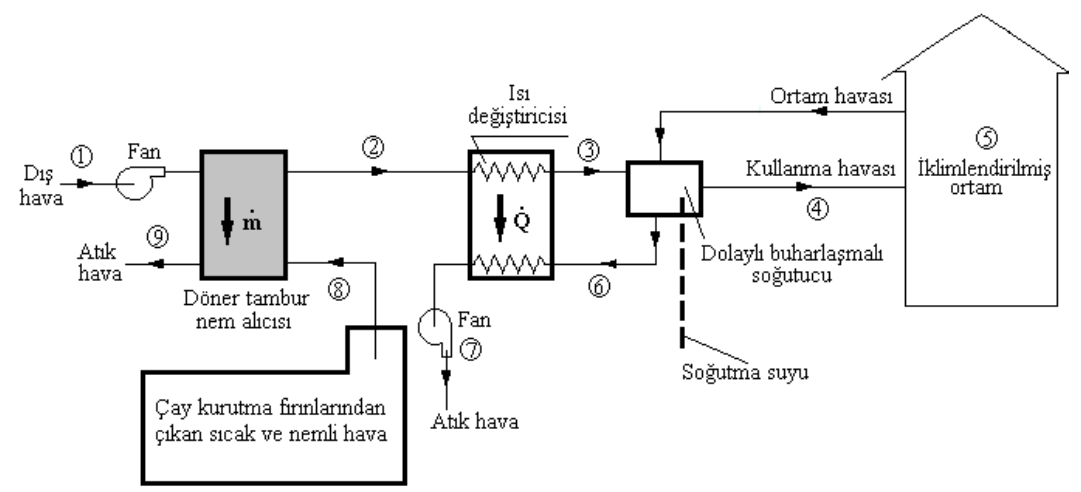

Şekil 3. İkinci işletim parametrelerine dayalı sistemin şematik resmi.

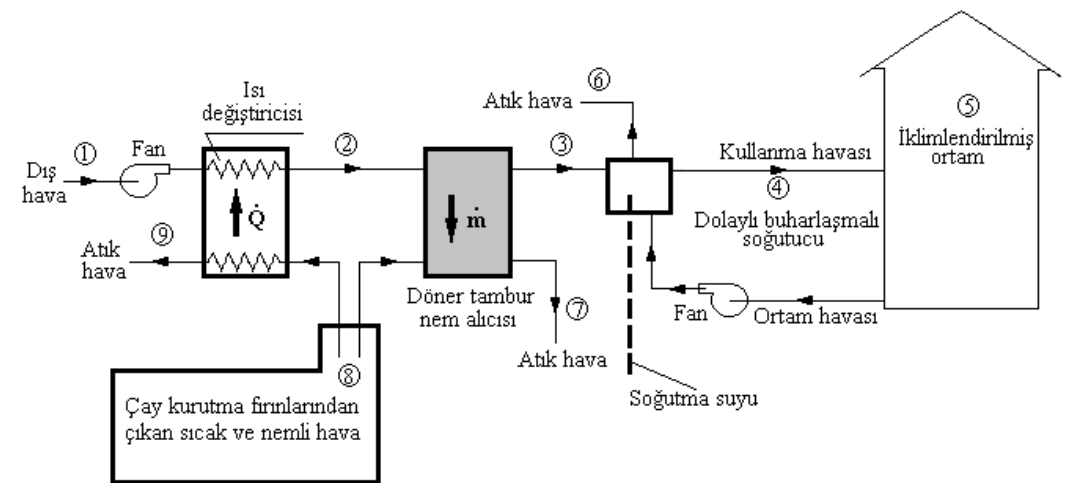

Şekil 4. Üçüncü işletim parametrelerine dayalı sistemin şematik resmi. 
B. SARAÇ. / Nem-alıcılı ve Buharlaşma-Soğutmalı Hava Şartlandırma Sistemlerinin Çay Fabrikalarında Kullanılabilirliğinin Termodinamik Analiz

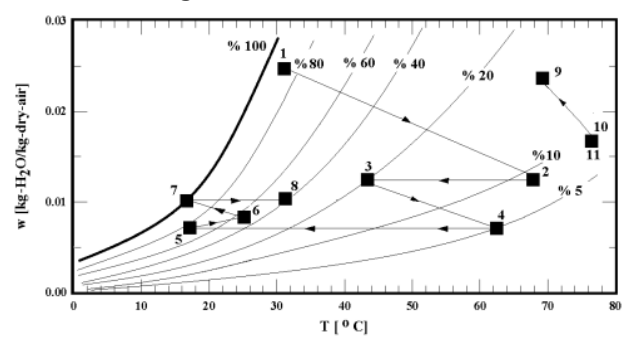

Şekil 5. Birinci işletim parametrelerine dayalı Termodinamik modelin süreçleri.

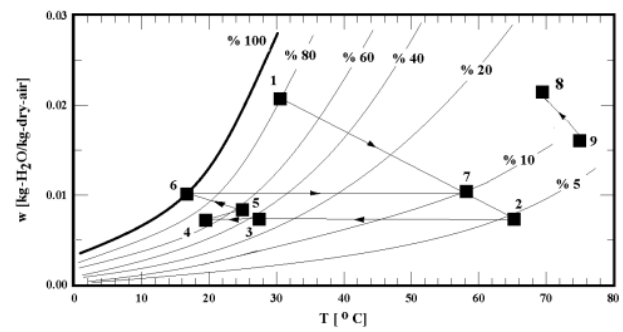

Şekil 6.İkinci işletim parametrelerine dayalı Termodinamik modelin süreçleri.

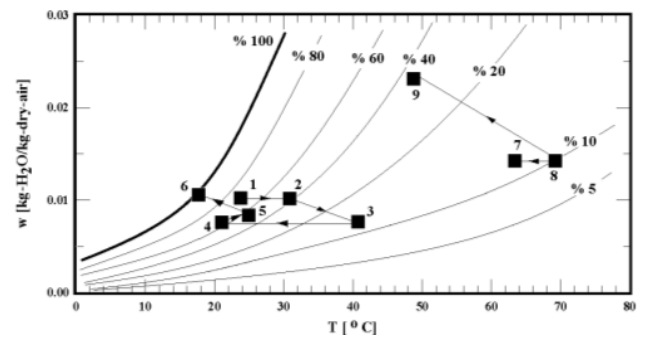

Şekil 7.Üçüncü işletim parametrelerine dayalı Termodinamik modelin süreçleri.

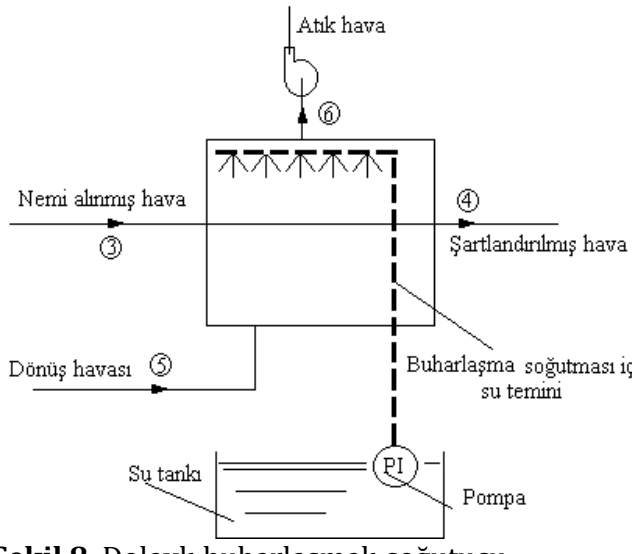

Şekil 8. Dolaylı buharlaşmalı soğutucu.
Termodinamik modelde, nem alıcı madde olarak Lityum klorür-seliloz kağıdı (LiCl-kağıdı) kullanılmıștır. LiCl nem alıcısının, rejenerasyon sıcaklığına $\left(40^{\circ} \mathrm{C}-80^{\circ} \mathrm{C}\right)$ bağlı nem alma kapasitesi 2 ile $5 \mathrm{gram} / \mathrm{kg}$ değerleri arasındadır. Bunun yanında nem alma işleminde, döner tambur nem alıcısının devir sayısı da önemli olduğundan döner tanburun devir sayısı 10 devir/saat olarak alınmıştır.

Tasarlanan sistem, çay fabrikası ofis binasının soğutulması işleminde enerji tasarrufu açısından dönüş havası ve temiz hava karışımını kullanmaktadır. Sistemde iki hava kanalı bulunmaktadır. Birinci kanalda dıș hava, döner tambur nem alıcısından geçirilerek nemi azaltıldıktan sonra ısı değiştiricisinden geçirilerek sıcaklığı düşürülür. Müteakiben dönüş havası ile karıştırılarak, doğrudan ve dolaylı buharlaşmalı soğutucularla soğutulduktan sonra iklimlendirilecek ortama gönderilir. İkinci kanal ise rejenerasyon hava kanalı olarak adlandırılmaktadır. Burada, dıș hava ilk önce ısı değiştiricisinden geçirilerek ön isitılmaya tabi tutulduktan sonra atık ısıyı kullanarak ssıtılır. Akabinde döner tambur nem alıcısından geçirilerek atmosfere atılır. Böylece döner tambur nem alıcısının nem alma özelliği arttırılır. Çay fabrikalarının kurutma firınlarında çevreye atılan sıcak ve nemli hava, tasarlanan rejenerasyon havasını ısıtmak için kullanılmaktadır.

Dış hava kanalına (1) noktasından alınan havanın nemi, döner tambur nem alıcısında azaltılmakta (2) ve sıcaklığı ısı değiştiricisinde düşürülmektedir. (3). Dış havanın neminin azaltılması ve sıcaklığının arttırılması süreci Şekil 5' de psikometrik diyagramda gösterilmiştir $\quad(1 \rightarrow 2 \rightarrow 3)$. Şartlandırılan dış hava dönüş havası ile karıştırıldıktan sonra (4) dolaylı evaporatif soğutucudan geçirilerek sıcaklığı düșürülür (5), akabinde doğrudan evaporatif soğutucudan 
B. SARAÇ. / Nem-alıcılı ve Buharlaşma-Soğutmalı Hava Şartlandırma Sistemlerinin Çay Fabrikalarında Kullanılabilirliğinin Termodinamik Analiz

geçirilerek sıcaklığı düşürülürken nemi de ortam konfor şartlarını sağlayacak șekilde arttırılır (6). Rejenerasyon hava kanalında, dış hava (1) isı değiştiricisinden geçirilerek ön isıtmaya tabi tutulur (9), akabinde sıcak atık isı kaynağından bir ısı değiştiricisi vasitasiyla isitılarak (10) döner tamburda nem alıcısından geçirilip atmosfere terk edilir (11). Sicak atık isı kaynağından oluşan sıcak hava (12) isı değiştiricisinden geçen rejenerasyon havasını ısıtmak için kullanılmaktadır. Şekil 5 de endirekt ve direkt evaporatif soğutucularında dış hava soğutma işlemlerinin Termodinamik süreçleri(4 $\rightarrow 5 \rightarrow 6)$ görülmektedir. Sistemde, dıș havayı șartlandırmak ve çıkış havasını dışarıya atmak için iki tane fan kullanılmaktadır. Fanların her birinin gücü $3.5 \mathrm{~kW}$ ve hacimsel debileri $6000 \mathrm{~m}^{3} / \mathrm{h}$ dir. Pompaların gücü $2 \mathrm{~kW}$ alınmıştır.

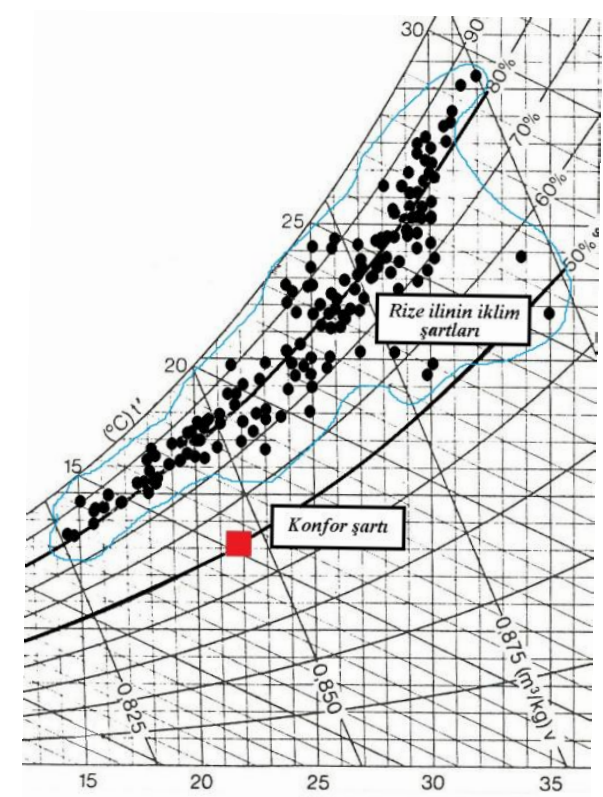

Şekil 9.2015 yılına ait Rize ilinin çay sezonunda iklim şartları ve ortam havası konfor şartı

Çay sezonunun Mayıs ayında başlayıp Eylül ayı sonlarında kapandığı Karadeniz ikliminde, sezon boyunca nem oranları ve sıcaklık değişimleri farklılık göstermekte olduğundan sistem konfigürasyonları iklim șartlarına (sıcaklık ve neme) göre belirlenmiștir. Şekil 9'da görülebileceği üzere Mayıs ve Nisan aylarında çevre sıcaklığı konfor sıcaklığından düşük iken çevre nemi konfor neminden yüksek olmakta ve konfor şartlarının sağlanması için, üçüncü işletim sisteminde çevre havasının neminin alınması ve isıtılması gerekmektedir. Üçüncü işletim sisteminde hava iklimlendirmesi ısıtma ve nem alma süreçleri olarak tanımlanmaktadır. Birinci ve ikinci işletim sistemlerinde hava iklimlendirilmesi nem alma ve soğutma süreçleri olarak ele alındığından, bu işletim sistemleri aynı prensipte çalışmaktadır. Temmuz ve Ağustos aylarında çevre havası neminin ortalama nem değerinden yüksek olması sebebiyle birinci işletim sistemine ikinci bir dönmeli tanbur ilave edilmiștir.

Seçilen ofis binasının duyulur ve gizli ısı kazanımları13.230kW ve $9.800 \mathrm{~kW}$ olarak hesaplanmıştır. Ortam havası kuru termometre sıcaklığ $24{ }^{\circ} \mathrm{C}$ ve bağll nemi \%50 olarak seçilerek ortam havası konfor şartları belirlenmiştir. Ortam havasının yaz şartları için iklimlendirilmesinde kullanılacak sistemin termodinamik analizinin yapılmasında sistemin bir modeli oluşturularak sistem performansını etkileyen değişkenler belirlenmiştir. Ortam havasının duyulur isı oranı,

$$
\begin{aligned}
D I O= & \frac{\text { Duyulur } 1 S 1}{\text { Duyulur } 1 \text { s1 }+ \text { Gizli } 1 S 1} \\
& =\frac{Q_{d}}{Q_{d}+Q_{g}}=0.6
\end{aligned}
$$

olarak ele alınmıştır. Duyurulur ısı ve gizli ısı aşağıdaki bağıntılarla hesaplanmıștır.

$$
\begin{aligned}
& \dot{Q}_{d}=\dot{m}_{a} C_{p}\left(\mathrm{~T}_{5}-T_{4}\right) \\
& \dot{Q}_{g}=\dot{m}_{a} h_{f g}\left(w_{5}-w_{4}\right)
\end{aligned}
$$


B. SARAÇ. / Nem-alıcılı ve Buharlaşma-Soğutmalı Hava Şartlandırma Sistemlerinin Çay Fabrikalarında Kullanılabilirliğinin Termodinamik Analiz

\subsection{Ele alınan modelin birinci ve ikinci işletim şartlarındaki} etkinliklerinin kıyaslanması:

Ele alınan model dış hava şartlarına göre, birinci ve ikinci işletim şartlarına göre çalıştırıldığında her iki işletim sistemi hem nem alma ve hem de soğutma yapmaktadır. Ancak üçüncü işletim iklim şartlarında çevre havası konfor sıcaklığından düşük buna karşılık çevre havası bağıl nemi konfor şartlarından çok yüksektir. Bu işletimde dış hava ön ısıtıcıdan geçirildikten sonra bir döner nem alıcıdan geçirilerek havanın nemi düşürüldükten sonra oluşan yüksek sıcaklığı azaltmak için dolaylı soğutucudan geçirilerek ortama üflenir.

Dıș ve rejenerasyon hava debileri birbirlerine eşit alınmıştır ve değeri $5217 \mathrm{~m}^{3} /$ saat olarak hesaplanmıştır. Sistemin soğutma etkinliğinin belirlenmesinde değişik etkinlik katsayıları tanımlanmıştır.

Ortam soğutmasına dayalı kullanma havasının performans katsayısı $\left(\mathrm{COP}_{\text {th }}\right)$ katsayısı,

$$
C O P_{t h}=\frac{\dot{Q}_{\text {sogutma }}}{\dot{Q}_{D N A}}=\frac{\dot{m}_{a}\left(h_{5}-h_{4}\right)}{\dot{m}_{r} C_{p}\left(T_{8}-T_{9}\right)}
$$

Taze havanının şartlandırma süreci performans katsayısı $\left(\mathrm{COP}_{\mathrm{ed}}\right)$,

$$
\operatorname{COP}_{e d}=\frac{\dot{Q}_{d i s}}{\dot{Q}_{D N A}}=\frac{\dot{m}_{a}\left(h_{1}-h_{4}\right)}{\dot{m}_{r} C_{p}\left(T_{8}-T_{9}\right)}
$$

Taze havanının şartlandırma süreci ısıl oranı $(\xi)$ ise ortam havasının soğutma yükünün, dış havanın duyulur isı miktarına oranı şeklinde ifade edilmiştir.

$$
\xi=\frac{\mathrm{m}_{\mathrm{a}}\left(\mathrm{h}_{5}-\mathrm{h}_{4}\right)}{\mathrm{C}_{\mathrm{p}} \mathrm{m}_{\mathrm{a}}\left[\left(\mathrm{T}_{1}-\mathrm{T}_{2}\right)-\left(\left(1+\mathrm{w}_{3}\right) \mathrm{T}_{3}-\left(1+\mathrm{w}_{2}\right) \mathrm{T}_{2}\right)\right]}
$$

$\mathrm{Bu}$ hesaplamalarda nem alıcı döner tambur etkinliği, ISı eşanjör etkinliği ve dolaylı buharlaştırıcı soğutucu etkinlikleri 1 alınmıştır. Nemli hava ideal gaz ve su buharı karıșımı olarak ele alınmıştır. Konfor şartları, parametre değerleri altındaki dış hava koșulları bu modelde kullanılmamıștır.

2.2. Ele alınan modelin birinci, ikinci ve üçüncü işletim şartlarındaki nem etkinlik katsayılarının kıyaslanması

Doğu Karadeniz iklim şartlarda ortamın isıl konforundan ziyade nem konforu öne çıktığından, bu üç işletim sistemin termodinamik performans analizi havadan çekilen nem miktarına bağlı olarak da incelenebilmektedir. Bu üç işletim sisteminin etkinlik kıyaslamasını yapabilmek için havadan nem giderme etkinlik katsayısı $\varepsilon$ tanımlanmıştır $[8,9]$ :

$$
\varepsilon=\frac{\dot{m}_{a} h_{f g}\left(w_{d 1 \text { hava }}-w_{\text {ortam havas1 }}\right)}{E_{\text {giren }}}
$$

Tanıtılan eșitliklerin ve nemli hava özelliklerinin hesaplanması için bir Excel programı yazllarak sonuçlar türetilmiştir.

\section{Bulgular}

Taze havanının şartlandırma süreci ısıl oranı, taze havanın artan özgül nem değerleriyle arttığı Şekil 10-a. dan görülmektedir. İkinci ve üçüncü ișletim sistemlerinde de aynı termal davranışlar bulunmuştur Şekil 11. ve Șekil 12.

Şekil 10-b. de ortam soğutması için kullanma havasının sağladığ $\breve{l}_{\text {soğutma }}$ etkinlik katsayı $\mathrm{COP}_{\text {th }}$ özgül nem arttıkça düşmektedir. Buna paralel olarak dış havanın şartlandırılmasında soğutma etkinlik katsayısının, özgül nem arttıkça azaldığı Şekil 10-c. de görülmektedir. Literatür [7] ve [8] de değişik iklim şartlarında benzer sonuçların elde edildiği görülmüştür. İkinci işletim şartlarında da aynı bulgular elde edilmiștir, Șekil 11-a-b-c. 
B. SARAÇ. / Nem-alıcılı ve Buharlaşma-Soğutmalı Hava Şartlandırma Sistemlerinin Çay Fabrikalarında Kullanılabilirliğinin Termodinamik Analizi
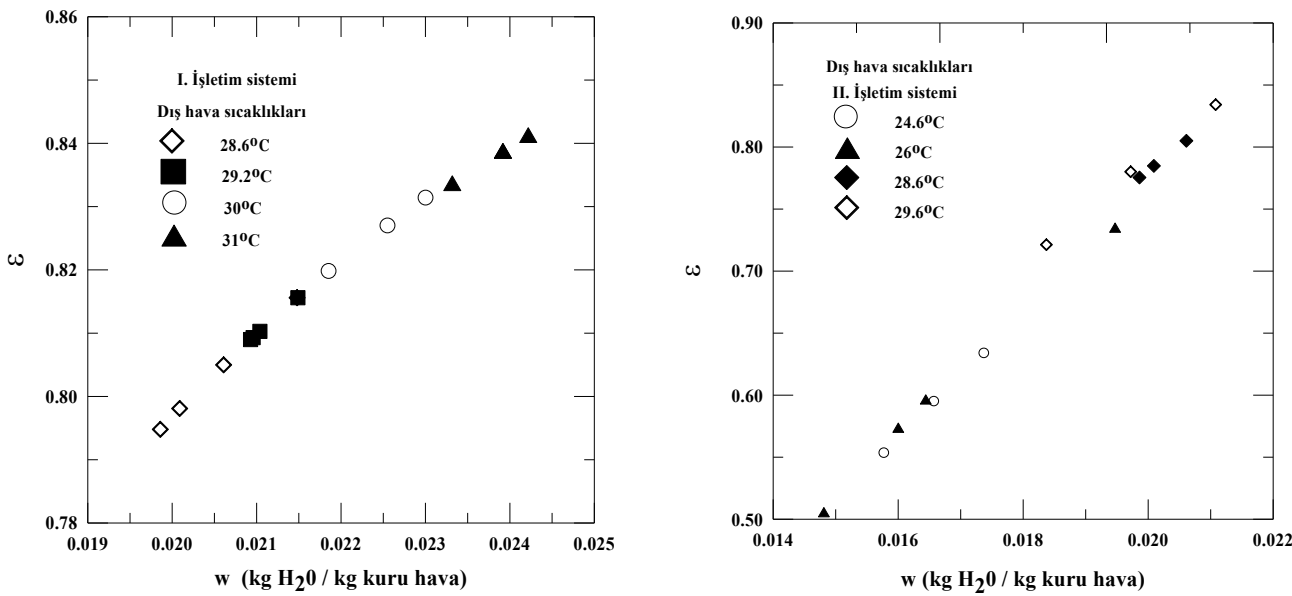

(a)

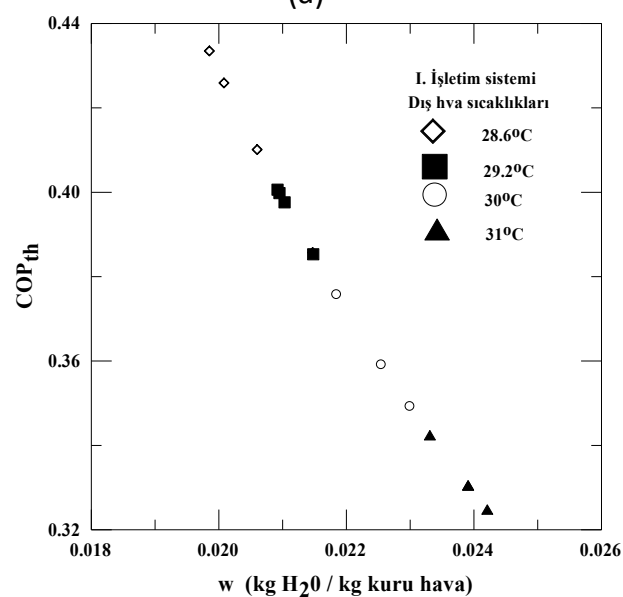

(b)

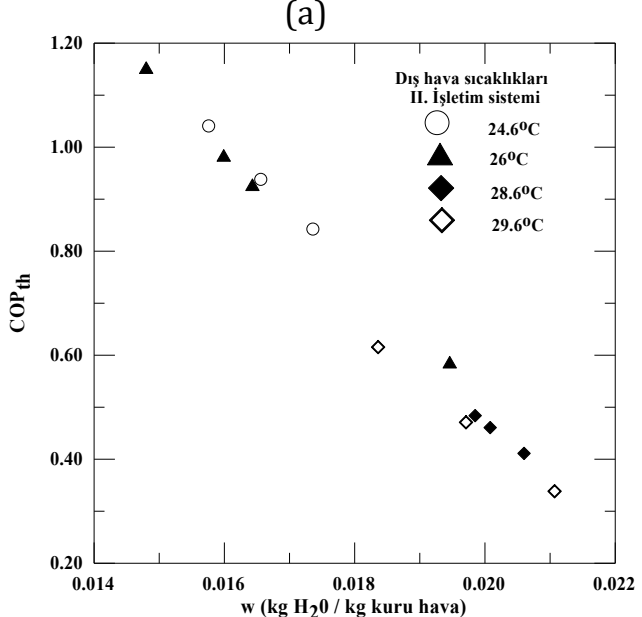

(b)

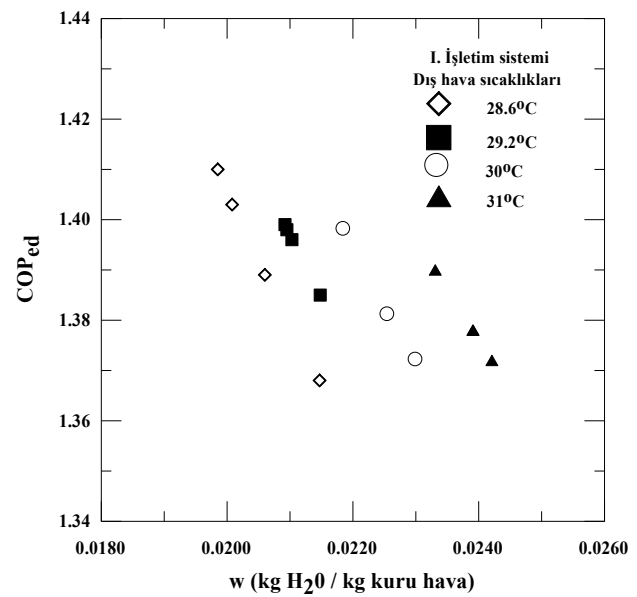

(c)

Şekil 10. Birinci işletim için özgül nem etkinlik değişim grafiği

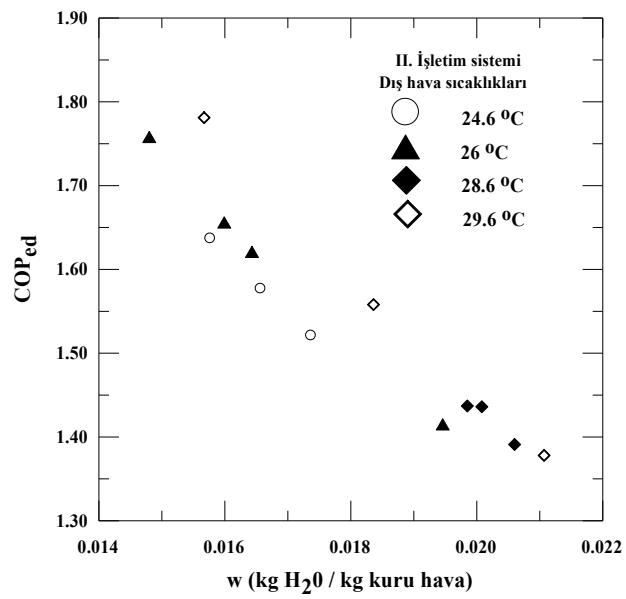

(c)

Şekil 11.İkinci işletim için özgül nem etkinlik değişim grafiği 
B. SARAÇ. / Nem-alıcılı ve Buharlaşma-Soğutmalı Hava Şartlandırma Sistemlerinin Çay Fabrikalarında Kullanılabilirliğinin Termodinamik Analizi

Isıl oranın, havanın değişik sıcaklık değerlerinde, dış havanın özgül neminin artmasıyla azaldığı Şekil 12-b. de görülmektedir.

Her üç sistemin nem alma etkinlik katsayısının, bir sezonluk çay üretimindeki dıș havanın özgül nem ve sıcaklık değerlerine göre sonuçları Şekil 13. de görülmüştür. Birinci ișletim sistemi Nisan ve Mayıs aylarına, ikinci işletim sistemi Haziran Temmuz, üçüncü işletim sistemi ise Ağustos ve Eylül iklim koşullarına dayalı sonuçları sunmaktadır.

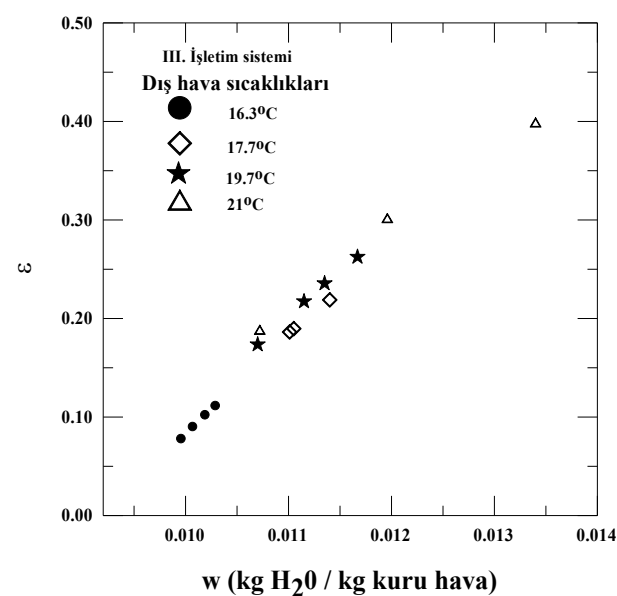

(a)

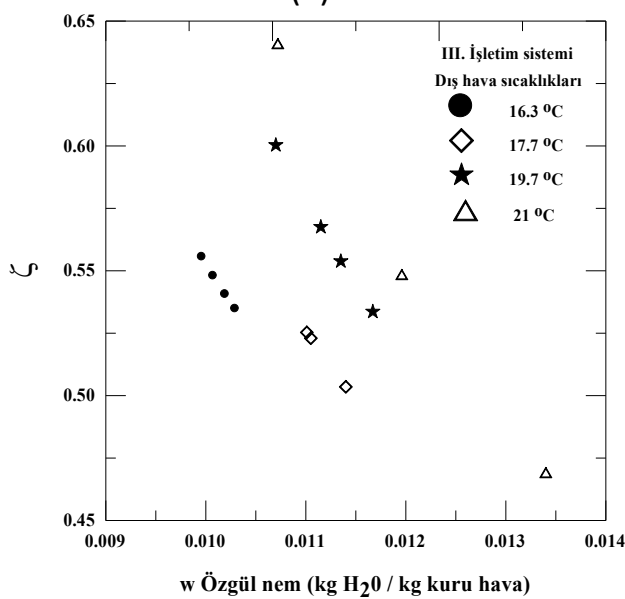

(b)

Şekil 12. Üçüncü ișletim için özgül nem Etkinlik değişim grafiği

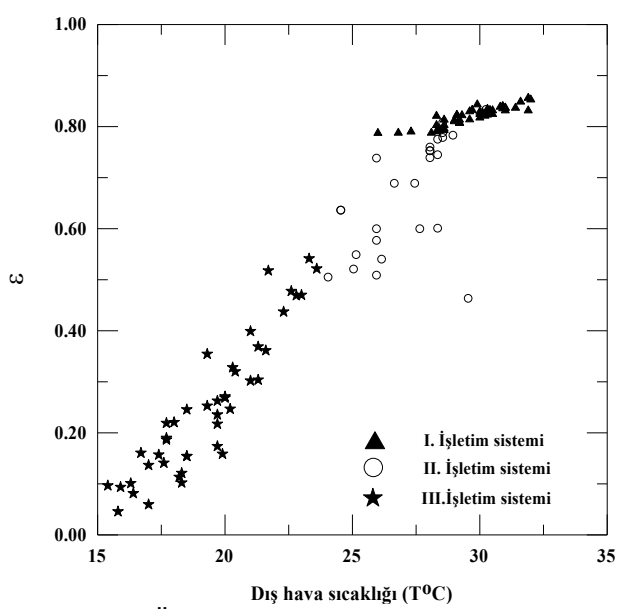

Sekil 13. Üc işletim sistemi için dıs hava sıcaklığı ile Etkinlik değişim grafiği

\section{Tartışma ve Sonuç}

Çay sezonu boyunca Soğutma etkinlik katsayısı en çok 1.44 ile en az 0.35 arasında, dıș hava șartları ile iklim şartlarına bağlı olarak değişmekte olduğu tespit edilmiştir.

Cay sezonu boyunca dıș hava iklim șartlarına göre, nem alma etkinlik katsayısının en çok 0.87 ile en az 0.11 arasında değiștiği görülmektedir.

Döner tambur nem alıcısının taze hava giriș debisi ile rejenerasyon hava debisi miktarlarının model üzerinde etkileri, daha sonraki çalışmaya bırakılmış olup bu çalışmada taze hava miktarı ile rejenerasyon hava debisi eşit alınmıștır.

Çay fabrikaları çay kurutma firınlarından atılan atık havanın, doğrudan rejenerasyon havası olarak kullanılmasıyla dış havanın neminin konfor sartlarına getirilmesinde büyük katkı sağladığı görülmüștür. Ayrıca bu metot ile ortam soğutulmasının başarıyla sağlandığı belirlenmiştir.

$\mathrm{Bu}$ çalıșmada üç farklı ișletim sisteminden hangisinin daha uygun ve ekonomik olduğuna dair karşılaştırmalar, çevre havasından çekilen nem miktarının büyüklüğüne dayalı olarak yapılmıştır. Üç farklı sistem kanfigürasyonunda da atık ısı döner tanbur nem alıcısındaki LiCl' nün kurutulması amacıyla kullanılmaktadır. Ele alınan ișletim sistemleri Şekil 13'de 
B. SARAÇ. / Nem-alıcılı ve Buharlaşma-Soğutmalı Hava Şartlandırma Sistemlerinin Çay Fabrikalarında Kullanılabilirliğinin Termodinamik Analiz

görülebileceği gibi etkinlik açısından değerlendirildiğinde, birinci işletim sisteminin \%80-\%90, ikinci ișletim sisteminin \%55-\%80, üçüncü ișletim sisteminin ise $\% 10$ ile $\% 50$ etkinlikte olduğu görülmüștür.

Çay fabrikalarında bulunan firınlardan atmosfere atılan sıcak gazların enerji değerinin, yaklaşık olarak 12.302.795 Türk lirası değerinde olduğu hesaplanmıştır. Enerji verimliliği açısından bu enerjinin yaşam mahallerinde ve ürün depolarında kullanılması büyük önem arz etmektedir. Tasarlanan iklimlendirilmiş ortam, soğutma yükü çevre havasına göre değerlendirildiğinde, birinci ișletim sistemi için sağlanan soğutma yükü maliyeti yaklaşı olarak 42.480 $\mathrm{TL} /$ sezon, ikinci işletim sisteminde ise yaklaşık olarak $10.512 \mathrm{TL} /$ sezon olarak hesaplanmıştır. $\mathrm{Bu}$ değerlerin hesaplanmasında, buhar sıkıștırmalı soğutma sisteminin soğutma etkinlik katsayısı $(\mathrm{COP}=1) 1$ olarak alınmıștır. Rize'nin yağıșlı ikliminden dolayı soğutma suyu maliyetinin az olması sebebiyle, tanıtılan sistemde soğutma suyu maliyeti ihmal edilmiştir. Ele alınan modelde soğutulan mahalin soğutma yükü $24.6 \quad \mathrm{kw}$ olarak hesaplanmış olup, bu tip işletim sistemlerinin daha yüksek soğutma yükleri için de kullanışlı olacağı görülmektedir.

Tanıtılan sistemlerin, atık enerjiyi doğrudan değerlendirmesi ve çevre dostu işletme şartlarını sağlamasından dolayı fabrikalarda bu tür sistemlerin kullanılması tavsiye edilmektedir.

\section{Kaynakça}

[1] Yilmaz,T., Bulut, H., Özgören,M. ve Büyükalaca, O., 1998. An alternative cooling system for hot, arid regions", pp.422-432, Proceeding of Int. Conference on Energy Research and Development, Kuwait, Vol.1,9-11.
[2] Yılmaz,A., Büyükalaca.0. ve Yılmaz.T., Ağustos 1998. Nem almalı (desesif) soğutma sistemleri, sh.145-150, Uluslararası Enerji Teknoloji ve Tesisat Dergisi.

[3] Shalot,M., ve Riffat,S.B., Dessicant cooling systems: a review, International Journal of LowCarbon Technologies, Vol.0, pp.117, January 20, 2016.

[4] Warke,A.D., ve Deshmukh,S., 2016 Study on development of rotary desiccant dehumidification from air conditioning point of view, International Journal of Modern Trends in Engineering and Research, Vol.3, pp.955-959.

[5] Kağanoğlu M, Bolattürk, A., Altıntop, N., 2007. Effect of ambient conditions on fist and second law performance of an open dessicant cooling process, Renew. Energy 32, 931-946.

[6] Elgendy, E., Mostofa, A., and Fatouh, M., 2015. Performance enhancement of a dessivant evoparative cooling system using direct/indirect evaporative cooler, Int. Journal of Refrigeration 51, ,7787.

[7] Rachman, A., Enggsa, Z., Mat, S., and Sopain, K., 2014. Performance of solid desiccant cooling with solar energy in hot and humid climate, Journal of Sustainability Science and Management Volume 9 Number 1, 150-155. ISSN: 18238556.

[8] Panaras, G., Mathioulakis, V., and Belessiotois, V., 2011. Solid desiccant air-conditioning systems Design parameters, Energy, Energy 36, 2399-2406,DOİ: 10.1016.

[9] Kağanoğlu, M., 2004. Energy analysis of an experimental opencycle desiccant cooling system, Applied Thermal Engineering, 24, 919-932. 
B. SARAÇ. / Nem-alıcılı ve Buharlaşma-Soğutmalı Hava Şartlandırma Sistemlerinin Çay Fabrikalarında Kullanılabilirliğinin Termodinamik Analizi

\section{Semboller}

\begin{tabular}{|c|c|}
\hline$\dot{m}$ & kütlesel debi (kg/s) \\
\hline$\dot{Q}$ & ISı $(\mathrm{kW})$ \\
\hline $\mathrm{w}$ & özgül nem (g $\mathrm{H}_{2} \mathrm{O} / \mathrm{kg}$ kuru \\
\hline hava) & \\
\hline $\mathrm{h}$ & entalpi $(\mathrm{kJ} / \mathrm{kg})$ \\
\hline $\mathrm{C}_{\mathrm{p}}$ & özgül ısı $(\mathrm{kJ} / \mathrm{kgK})$ \\
\hline DNA & döner nem alıcı tambur \\
\hline COP & soğutma etkinlik katsayısı \\
\hline$\varepsilon$ & etkinlik katsayısı \\
\hline$\xi$ & ısıl oranı \\
\hline İndisler & \\
\hline $\mathrm{a}$ & diș hava \\
\hline r & rejenerasyon \\
\hline $\mathrm{d}$ & duyulur \\
\hline g & gizli \\
\hline th & Isı kullanımına dayalı \\
\hline ed & taze hava şartlandırma süreci \\
\hline
\end{tabular}

